\title{
A Comparative Study of Present Status of Marketing of Formalin Treated Fishes in Six Districts of Bangladesh
}

\author{
Rafiad Islam*, Shahin Mahmud, Abdul Aziz, Animesh Sarker, Marufa Nasreen \\ Department of Biotechnology and Genetic Engineering, Mawlana Bhashani Science and Technology University, \\ Tangail, Bangladesh \\ Email: rafiadbmb1896@gmail.com, shahin018mbstu@gmail.com, aziz24bd@yahoo.com, \\ animesh du geb@yahoo.com, nasreen.marufa@gmail.com
}

Received 27 December 2014; accepted 8 January 2015; published 13 January 2015

Copyright (C) 2015 by authors and Scientific Research Publishing Inc.

This work is licensed under the Creative Commons Attribution International License (CC BY). http://creativecommons.org/licenses/by/4.0/

cC) (7) Open Access

\section{Abstract}

The fish is an important food stuff and source of protein all over the world. In Bangladesh, fisheries sector contributes a lot, in the case of the earning foreign currency and meeting domestic need of the animal proteins. To fulfill the domestic need of protein and fish, Bangladesh imports fish and fish products from the neighboring county. In many studies, it was proved that most of the imported fishes are contaminated with formalin, which is the highly hazardous and carcinogenic chemical. Information was collected from the fish retailers and consumers on the marketing of the formalin treated fishes through survey using prescribed questionnaire at 18 different fish markets in 6 different districts of Bangladesh. It was found that most of the commercially imported fishes are highly contaminated with formalin. On the other hand, local big fishes, such as rui (Lobeo Rohita), catla (Catla catla) and mrigal (Cirrhinus cirrhosus) etc., are also formalin contaminated partially, but not all the fishes. All the local small fishes are free from the formalin contamination. In this study, it was found that, among the 939 fish samples collected from the different fish markets of the six districts, 213 fishes $(22.68 \%)$ were directly contaminated with formalin. The contamination rate is so much higher in the big city like Dhaka $(36.78 \%)$ and lower in the small town like Jamalpur districts $(13.33 \%)$. This study also indicated that, all the village markets were totally free from the formalin contamination. As the fish traders used formalin to increase the shelf life of the fishes, it was also observed that, the shelf life of the local fishes or formalin free fishes was much higher and the organoleptic characteristics were much more excellent than the formalin contaminated local or imported fishes. The price of the imported fishes was also lower than the local fishes. It was also clear that, the organoleptic characteristics of the imported fishes and formalin contaminated fishes were greatly different than the local fishes, which were not satisfactory to the consumers. The study also indicated that, the overall hygienic practice and sanitary condi-

\footnotetext{
${ }^{*}$ Corresponding author.
}

How to cite this paper: Islam, R., Mahmud, S., Aziz, A., Sarker, A. and Nasreen, M. (2015) A Comparative Study of Present Status of Marketing of Formalin Treated Fishes in Six Districts of Bangladesh. Food and Nutrition Sciences, 6, $124-134$. 
tions of the markets and the fish traders/retailers were very poor, not satisfactory. This survey also revealed that, all the traders or retailers who were mixed formalin with the fishes, knew about the bad effects of the formalin.

\author{
Keywords
}

Formalin, Fish, Dhaka, Protein

\title{
1. Introduction
}

Bangladesh has a vast fisheries resource comprising of fresh, brackish and marine water. Those are inhabited by 296 fresh and brackish water species, 511 marine species, 14 exotic species of fish and 24 species of prawn [1]. It is claimed that the total fish production has increased significantly over the last few decades [1] but it is not sufficient to meet the growing demand of the country [2]. So to meet the growing demand of the people, it is reported that more than $80 \mathrm{MT}$ of fish and fishery products enter into Bangladesh every day through the Teknaf border from Myanmar [3].

Bangladesh is a developing country. About $90 \%$ of animal protein in our diet comes from fish and livestock [4]. Fish and fishery products are the country's third largest export commodity contributing $5.10 \%$ of its exchange earnings. In 2002-2003 Bangladesh earned US \$324 million of which shrimp alone contributed 72\% of the total by quantity and $89 \%$ by value [5].

By composition, fish contains fat free amino acids and water which is susceptible to spoilage by microorganisms and biochemical reactions during post mortem process [6] [7]. Available reports suggest that formalin is sometimes added or sprayed to the fishes by the fish traders while transporting to domestic marketing chain to prevent spoilage and increase shelf life [2]. Study is conducted at different markets in Dhaka City [8] [9] and Mymensingh Sadar [2] rationalizes the incidence of adding formaldehyde/formalin to fishes especially imported from neighboring countries. It is not known whether some local fishes are also sprayed with formalin to prevent their spoilage [3].

It is reported that, based on our preliminary study on the detection of formalin in fishes available in the domestic market and those conducted by the Fish Inspection and Quality Control (FIQC) office of the Department of Fisheries (DoF), the fish available in the domestic market is contaminated with formalin ranging from $0.5 \%$ $1 \%$ [2]. It also investigated the effect of formalin on the quality of rohu fish Labeo rohita [10] where it was seen formalin treatment significantly increased the shelf life of fish, but reduced protein solubility and eating quality of the fish itself.

Formaldehyde is the simplest member of aldehyde family but a very reactive chemical, where the gaseous form is known as formaldehyde and the liquid form as formalin [11]. Some studies suggest that large formaldehyde exposures, for example from drinking formaldehyde solutions, are potentially lethal [12]. Formaldehyde is converted to formic acid in the body, leading to a rise in blood acidity, slow breathing, hypothermia, and coma or death. People who have ingested formaldehyde require immediate medical attention. In the body, formaldehyde can cause proteins to irreversibly bind to DNA. Formaldehyde is listed as a probable human carcinogen. It is, therefore, important to make a detailed survey on the use of formalin in commercially important fishes.

Ingestion of as little as $30 \mathrm{~mL}$ ( $1 \mathrm{oz}$.) of formalin has been reported to cause death in an adult human being. Ingestion may cause corrosive injury to the gastrointestinal mucosa, with nausea, vomiting, pain, bleeding, and perforation. Corrosive injuries are usually most pronounced in the pharyngeal mucosa, epiglottis and esophagus. Systemic effects include metabolic acidosis, CNS depression and coma, respiratory distress, renal failure and associated cancer and tumor development [12]. Use of formalin in food is banned in Bangladesh; however, formalin contamination is reported to occur in table fish marketed in the country [1] [2].

Ang and Hultin (1989) reported that increased formaldehyde formation caused insolubility of protein due to denaturation. Ames and Poulter (1982) also reported the TMAO content in LF was high and DMA formed from TMAO could be used as a freshness index. The reaction of formalin and fish causes textural toughness in fish muscle due to the denaturation of proteins by formaldehyde.

Food safety has become an important issue and a widely talked word of modern age. It is a scientific discip- 
line describing handling, preparation, and storage of food in ways that prevent foodborne illness [13]. Many national and international agencies are working in collaboration to ensure food safety, and in most of the industrialized countries the issue of food safety, quality and environmental concerns are more important than the product price and income changes [14]. However, the situation is far different in the developing countries, where food and food ingredients gain access in the marketing channel which are possibly contaninated with different types of hazardous chemicals including formalin, dyes, insecticides, banned antibiotics etc. [2] [15].

Recently, International Agency for Research on Cancer (IARC) has classified formaldehyde as a Group 1 carcinogenic to humans (2004). According to the United States Environmental Protection Agency (EPA), maximum daily dose reference (RfD) for formaldehyde is $0.2 \mu \mathrm{g} / \mathrm{g}$ body weight per day [16]. In 1985, Italian Ministry of Health has proposed formaldehyde values of $60 \mu \mathrm{g} / \mathrm{g}$ and $10 \mu \mathrm{g} / \mathrm{g}$ for Gadidae (family of marine fish) and crustaceans (arthropods), respectively [17]. Nowadays available reports in the newspaper, the dishonest businessmen are using formalin in fish to keep freshness or shelf life for longer time without signs of spoilage [18].

In 2011, the National Toxicology Program, an interagency program of the Department of Health and Human Services, named formaldehyde as a known human carcinogen in its 12th Report on Carcinogens [19]. Though it is harmful and potential source of health hazard to human some fish traders are engaged in treating fish with formalin [20]. It was observed in a study conducted in Dhaka City [9] that almost 5\% shops of total consumable fishes contain formalin treated fishes those are sold in fish markets. Use of formalin in food for human consumption is also banned in Bangladesh [10]. Recently, International Agency for Research on Cancer (IARC, 2004) has classified formaldehyde as a Group 1 carcinogenic to humans. According to the United States Environmental Protection Agency (EPA), maximum daily dose reference (RfD) for formaldehyde is $0.2 \mu \mathrm{g} / \mathrm{g}$ body weight per day [11] [16]. Even those who spray or inject formalin over a long period of time will likely suffer health complications such as blindness, asthma and even lung cancer [21]. Considerable information is available on the shelf life of fish under various storage conditions by determining organoleptic and physical characteristics [22] studied the combined effect of Initial microbial count, storage temperature and $\mathrm{CO}_{2}$ flushing of the package on shelf-life of fresh fish.

The $\mathrm{pH}$ of living fish, although generally between 6.7 and 7.0, is subjected to variation with time of year, feeding, and degree of activity of the fish [23]. Almost all freshwater fish inhabit waters with a pH from 5.0 - 9.0, with the majority of these inhabiting water with a slightly acidic to neutral $\mathrm{pH}(6-7.5)$ [24]. $\mathrm{pH}$ first decreases with the onset of rigor but then progressively increases from microbial activity. For some fish, a pH value greater than 7.0 indicates spoilage [23]. The $\mathrm{pH}$ in fish tissues drops due to smoking (as preservative), generally to 6.5 or less. During the aerobic storage, specific spoilage bacteria should be around $10^{8}$ to $10^{9} \mathrm{cfu} / \mathrm{g}$ to produce significant amount of chemical compounds associated with spoilage. These results are in agreement with putrescine and cadaverine forming bacteria in anchovies stored in ice [25]. For transportation of fresh fish, crushed ice is mostly used for chill preservation, and there involves washing and sprinkling of freshwater on fish in the retail market [26]. Washing fish before and/or processing or during chilled storage has positive effect on shelf life because washing takes away a proportion of the microorganisms on the outer surface of the fish, thus reducing the number of bacteria capable of penetrating the muscle by diffusion [27]. The grading of fish using score on the characteristics has been followed by Multilingual Guide to EC Freshness Grades for Fishery Products [28] to judge the quality of the fish. [29] reported that bacterial cell division was inhibited in 20 to $50 \mu \mathrm{g} / \mathrm{mL}$ (equals to $2 \%-5 \%$ ) of formaldehyde. Since formalin is $37 \%$ formaldehyde in water, the concentration of $10 \%$ used in the present study was almost equal to that reported by [29] which inhibited bacterial cell growth.

Quality loss also occurs due to rough handling when the fishes are transported to market with ice by means of trucks, carrier launches and rail way for short and long distance transport [26].

We want to show an overall picture of formalin treated or untreated, local or imported fish trading in different market of Bangladesh.

\section{Materials and Method}

\subsection{Fish Sample Collection}

There are many fish markets are available in the Bangladesh. At first we selected six districts named—Dhaka, Tangail, Mymensingh, Sherpur, Jamalpur and Manikgonj. As there were many fish markets in every district, so three markets were selected for the fish sample collection from the each district. From each bazaar, at least three samples of each type of fish are collected. As a result, nine fish samples were collected for each type of fish 
from each district. The fishes were collected from the both town market and the village market in every district, except the Dhaka district. About twenty types of fishes and at least 150 fishes sample were collected from the every district. Some ice freezing fishes and both local and imported fishes were collected on the basis of their availability. The bazaar and fish samples were collected randomly. On the basis of the organoleptic characteristics such as color, odour of neck where broken, odour of gills, general appearance eye, slime and the consistency of the flesh were recognized between locally produced and imported ones of fishes. The fishes were immediately transported to the laboratory and subsequently tested for the formalin detection. Various fish sample e.g. mrigal (Cirrhinus cirrhosus), rui (Labeo rohita), kal baoush (Labeo calbasu), katol (Catla catla), silver karp (Hypophthalmichthys molitrix), boal (Wallago attu), elish (Tenualosa ilisha), telapia (Oreochromis mossambicus), aaeer (Sperata aor), baeen (Mastacembelus armatus), chitol (Chitala chitala), foli (Notopterus notopterus), koi (Anabas testudineus), sorputi (Puntius sarana), etc. were collected from selected wet markets.

\subsection{Qualitative Detection of the Formalin}

At first, the samples were washed with small quantity of water. Three drops washed-out water was taken in a test-tube using a dropper. Formalin detection kit in food developed by Bangladesh Council of Scientific and Industrial Research (BCSIR) was used in this experiment which is shown in Figure 1. The kit contains three solutions (No. 1-3). Added 15 drops from solution No. 1 in the test-tube containing washed-out water. After well stirring, the solution was allowed to wait for 30 seconds. Then 15 drops from solution No. 2 were added in the same test-tube containing solution. After well stirring, the solution was also allowed to wait for 30 seconds. After then 15 drops from solution No. 3 were added in the same test-tube containing solution. After adding No. 3 solution, if the color of the solution changes into pink or red color, the presence of formalin will be ensured. On the other hand, if the color of the solution remains unchanged, there is no formalin in the sample.

\section{Result and Discussion}

Studies were conducted on the detection of the formalin in fish obtained from different wet markets in the six district of Bangladesh and the results are presented in the Tables 1-7. It were found that in many 939 fishes sample, 213 fishes were contaminated with formalin in which 14.66\% in Tangail District (sample-150, formalin contaminated-32), 36.78\% in Dhaka District (sample-174, formalin contaminated-64), 26\% in Mymensingh District (sample-156, formalin contaminated-41), 14.00\% in Sherpur District (sample-150, formalin contaminated-21), 13.33\% in Jamalpur District (sample-150, formalin contaminated-20), and 22.00\% in Manikgonj District (sample-159, formalin contaminated-35).

It is found that, the fishes collected from the village markets were $0 \%$ formalin contaminated and all the formalin contaminated fishes are found in the town market. The local and small fishes are so less formalin contaminated, in the other hand, the big fishes are frequently contaminated. The study indicates that the formalin contamination rate is so much higher in the big town area (Dhaka-36.78\%, Mynmensingh-26.28\%) and lower in the small town area (Sherpur-14\%, Jamalpur-13.33\%). It has been shown that among the local fishes, 40.74\% Mrigal (sample—54, contaminated—22), 38.89\% Rui (sample—54, contaminated—21), 55.56\% Katol

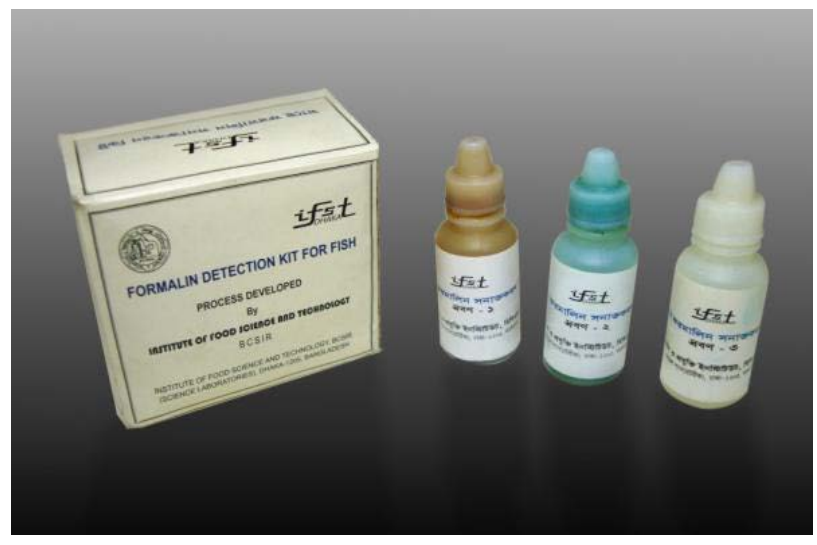

Figure 1. Formalin detection kit for fish developed by BCSIR. 
Table 1. Formalin detection in fish in Tangail District.

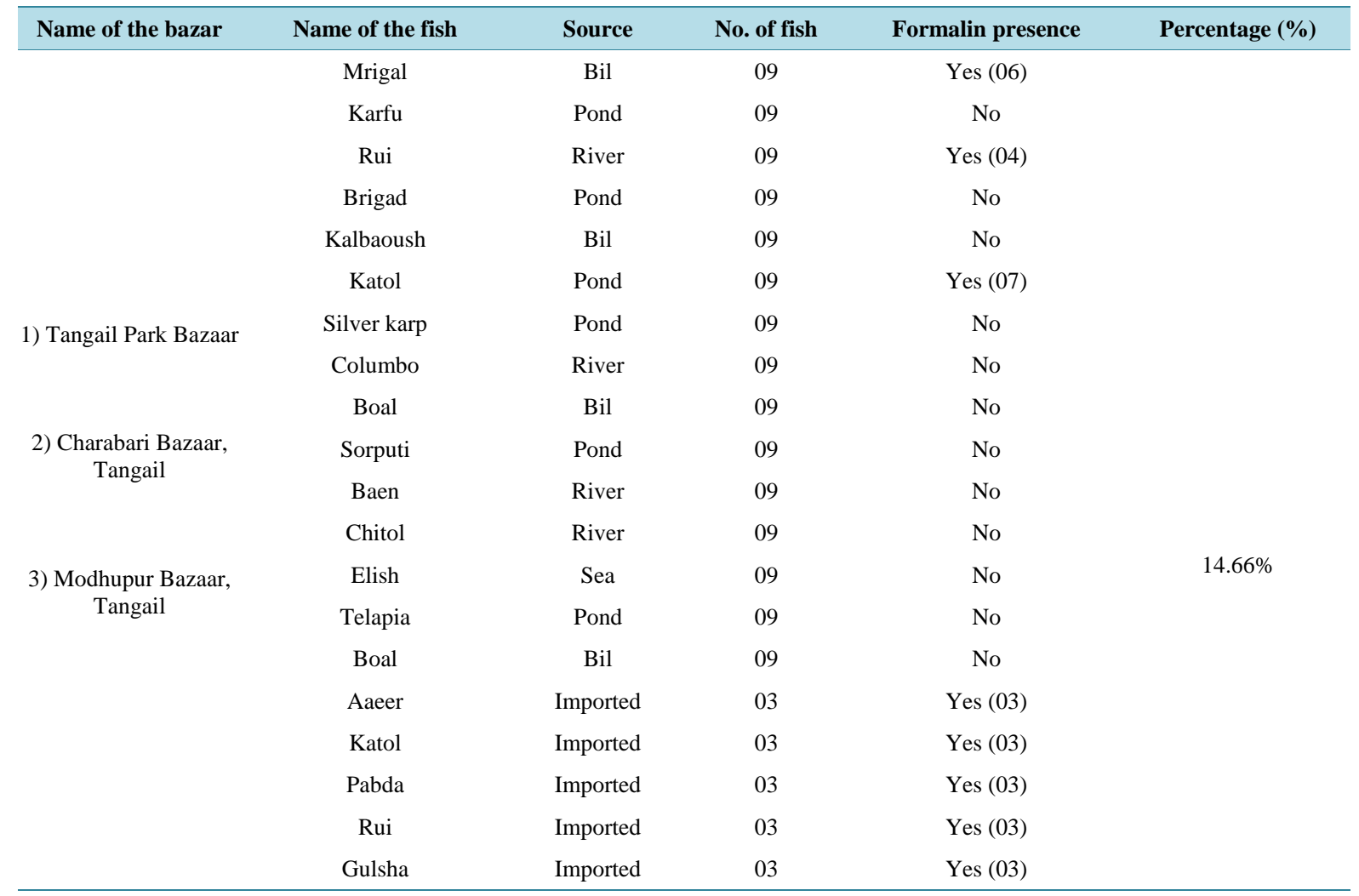

Table 2. Formalin detection in fish in Dhaka District.

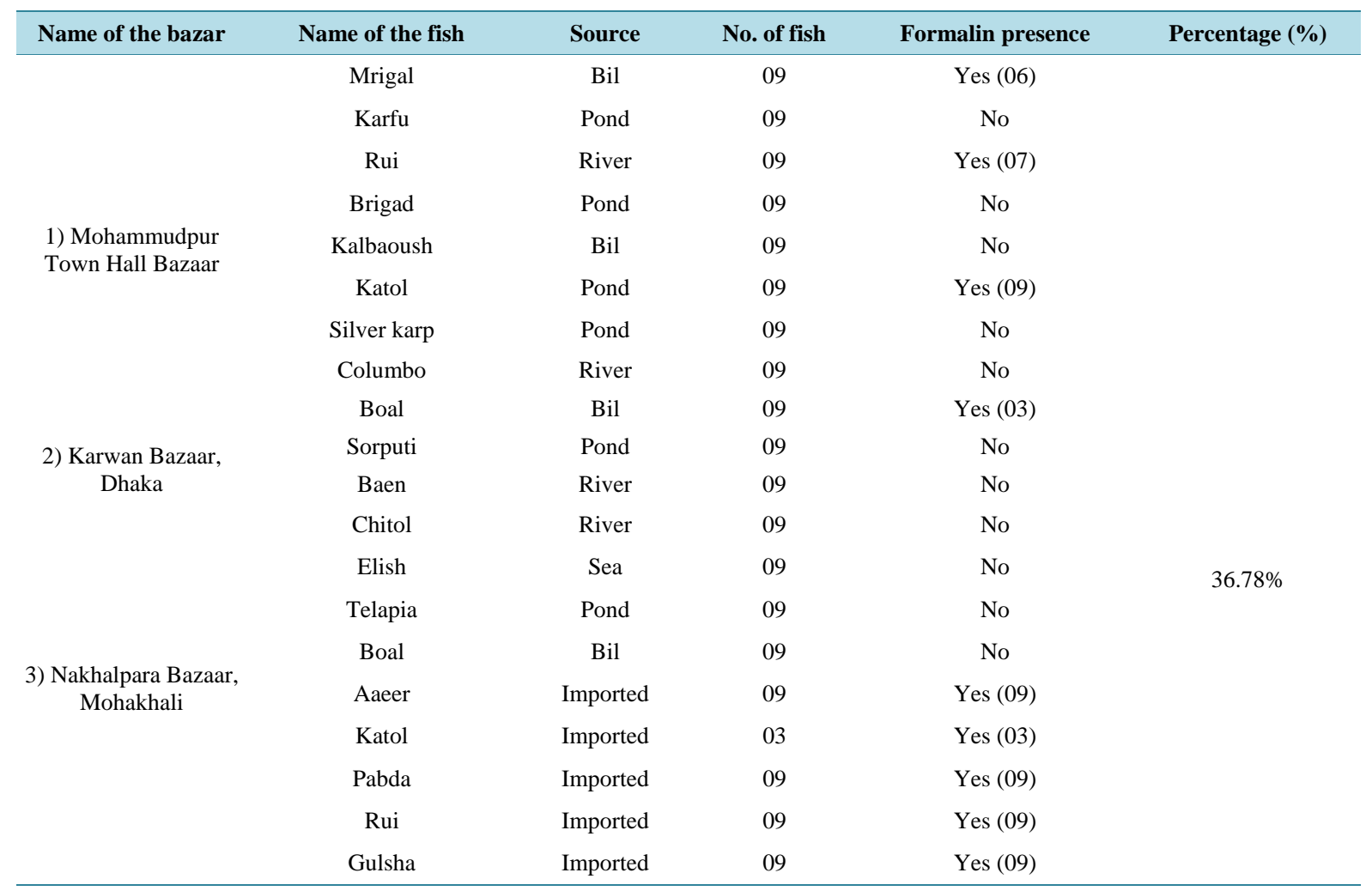


Table 3. Formalin detection in fish in Mymensingh District.

\begin{tabular}{lccccc}
\hline Name of the bazar & Name of the fish & Source & No. of fish & Formalin presence & Percentage (\%) \\
\hline Mrigal & Bil & 09 & Yes (05) \\
Karfu & Pond & 09 & No \\
Rui & River & 09 & Yes (04) \\
Brigad & Pond & 09 & No \\
1) Shankipara Bazaar & Kalbaoush & Bil & 09 & Yes (06) \\
& Katol & Pond & 09 & Yes (05) \\
& Silver karp & Pond & 09 & No \\
Columbo & River & 09 & No \\
Boal & Bil & 09 & No \\
Sorputi & Pond & 09 & No \\
Baen & River & 09 & No \\
Chitol & River & 09 & No \\
Elish & Sea & 09 & No \\
Telapia & Pond & 09 & No \\
Boal & Bil & 09 & No \\
Aaeer & Imported & 06 & Yes (06) \\
Katol & Imported & 03 & Yes (03) \\
Pabda & Imported & 03 & Yes (03) \\
Rui & Imported & 06 & Yes (06) \\
Gulsha & Imported & 03 & Yes (03) \\
\hline
\end{tabular}

Table 4. Formalin detection in fish in Sherpur District.

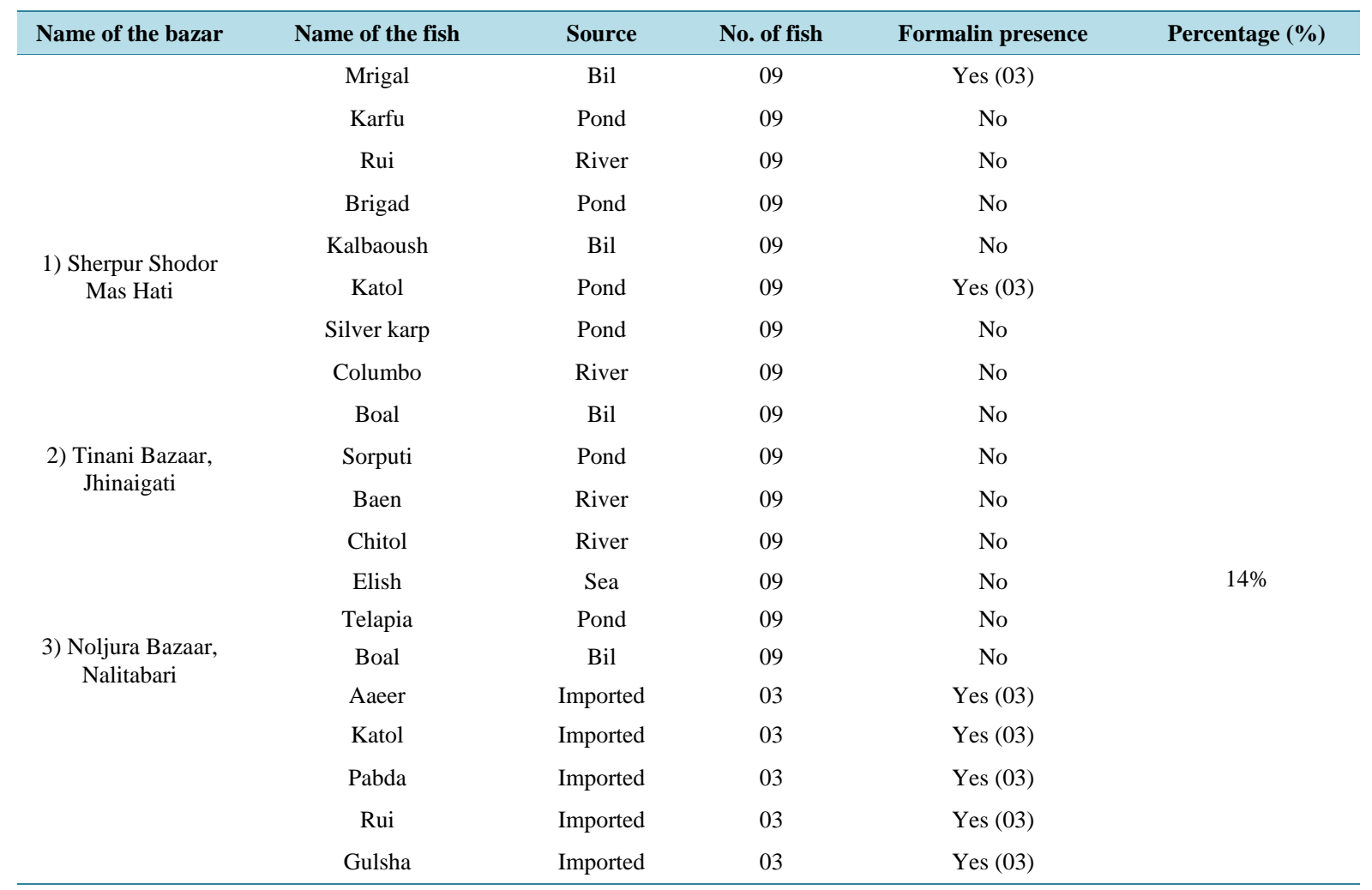


Table 5. Formalin detection in fish in Jamalpur District.

\begin{tabular}{|c|c|c|c|c|c|}
\hline Name of the bazar & Name of the fish & Source & No. of fish & Formalin presence & Percentage (\%) \\
\hline \multirow{7}{*}{$\begin{array}{l}\text { 1) Jamalpur Shodor } \\
\text { Mas Hati }\end{array}$} & Mrigal & Bil & 09 & No & \\
\hline & Karfu & Pond & 09 & No & \\
\hline & Rui & River & 09 & Yes (02) & \\
\hline & Brigad & Pond & 09 & No & \\
\hline & Kalbaoush & Bil & 09 & No & \\
\hline & Katol & Pond & 09 & Yes (03) & \\
\hline & Silver karp & Pond & 09 & No & \\
\hline \multirow{4}{*}{ 2) Shorishabari Bazaar } & Columbo & River & 09 & No & \\
\hline & Boal & Bil & 09 & No & \\
\hline & Sorputi & Pond & 09 & No & \\
\hline & Baen & River & 09 & No & \\
\hline \multirow{9}{*}{$\begin{array}{l}\text { 3) Jamalpur Kacha } \\
\text { Bazaar }\end{array}$} & Chitol & River & 09 & No & \\
\hline & Elish & Sea & 09 & No & $13.33 \%$ \\
\hline & Telapia & Pond & 09 & No & \\
\hline & Boal & Bil & 09 & No & \\
\hline & Aaeer & Imported & 03 & Yes (03) & \\
\hline & Katol & Imported & 03 & Yes (03) & \\
\hline & Pabda & Imported & 03 & Yes (03) & \\
\hline & Rui & Imported & 03 & Yes (03) & \\
\hline & Gulsha & Imported & 03 & Yes (03) & \\
\hline
\end{tabular}

Table 6. Formalin detection in fish in Manikgonj District.

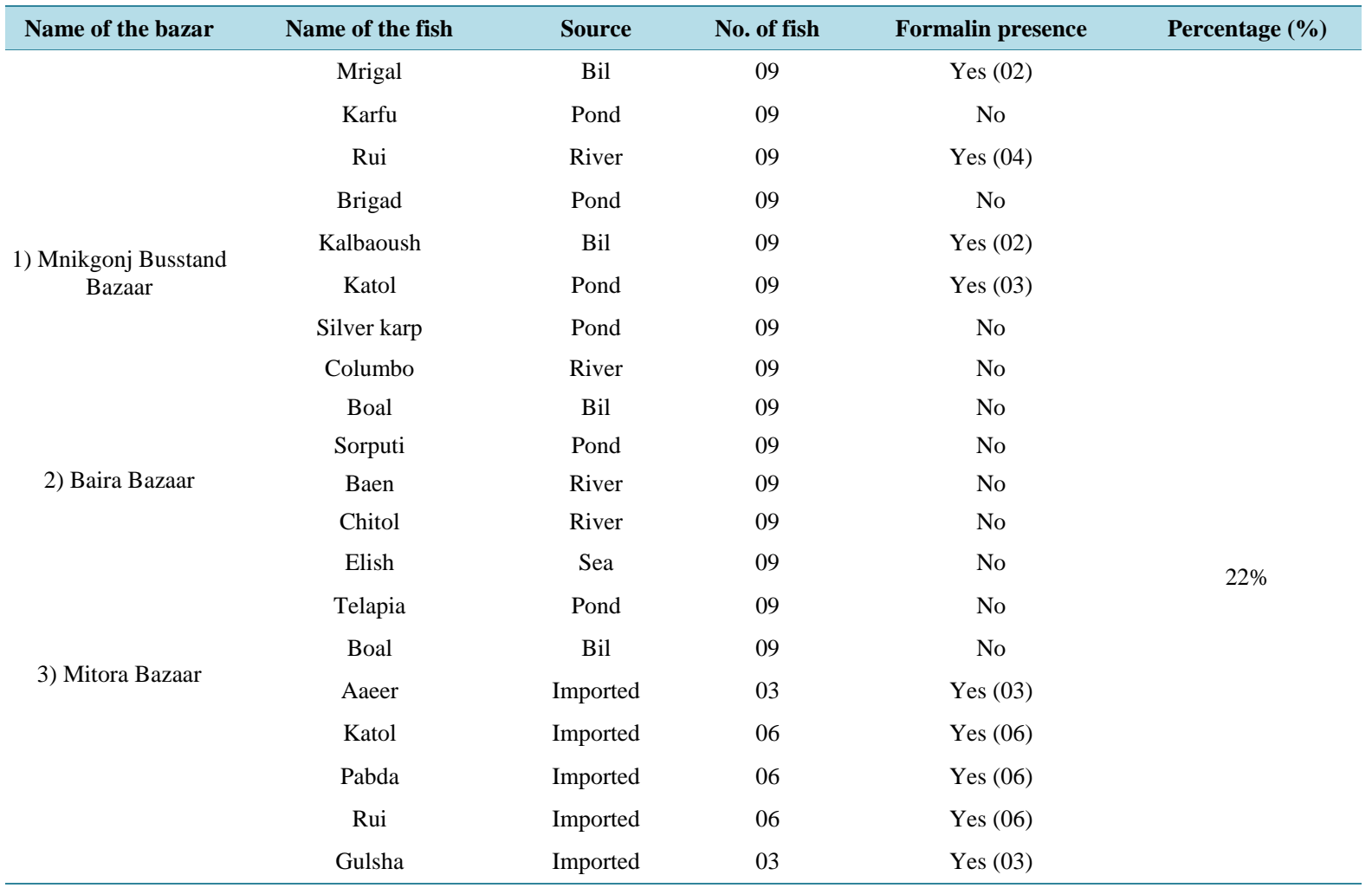


Table 7. Determination of defect points between locally available fish and imported fish of the same species.

\begin{tabular}{|c|c|c|c|c|c|c|c|c|c|}
\hline \multirow{2}{*}{ Species } & \multicolumn{7}{|c|}{ Defect characteristics } & \multirow{2}{*}{$\begin{array}{l}\text { Defect } \\
\text { points }\end{array}$} & \multirow{2}{*}{$\begin{array}{c}\text { Overall } \\
\text { grade }\end{array}$} \\
\hline & Odor & $\begin{array}{l}\text { Odor of } \\
\text { gill }\end{array}$ & $\begin{array}{l}\text { Color of } \\
\text { gill }\end{array}$ & $\begin{array}{c}\text { General } \\
\text { appearance }\end{array}$ & Eye & Slime & $\begin{array}{c}\text { Consistency } \\
\text { of flesh }\end{array}$ & & \\
\hline $\begin{array}{c}\text { Rohu } \\
\text { (local) }\end{array}$ & $\begin{array}{c}\text { Natural } \\
\text { odour }\end{array}$ & $\begin{array}{c}\text { Natural } \\
\text { odour }\end{array}$ & $\begin{array}{c}\text { Slight } \\
\text { pinkish red }\end{array}$ & $\begin{array}{l}\text { Full bloom; } \\
\text { bright; } \\
\text { shining }\end{array}$ & $\begin{array}{l}\text { Bulging with } \\
\text { protruding } \\
\text { lens }\end{array}$ & $\begin{array}{l}\text { Usually clear, } \\
\text { transparent }\end{array}$ & $\begin{array}{l}\text { Firm and } \\
\text { elastic }\end{array}$ & 1 & Excellent \\
\hline $\begin{array}{c}\text { Rohu } \\
\text { (imported) }\end{array}$ & $\begin{array}{c}\text { Some } \\
\text { loss of } \\
\text { natural } \\
\text { odour }\end{array}$ & $\begin{array}{c}\text { Slight } \\
\text { moderate to } \\
\text { strong sour } \\
\text { odour }\end{array}$ & $\begin{array}{l}\text { Brown or } \\
\text { grey color }\end{array}$ & $\begin{array}{c}\text { Definite } \\
\text { dullness and } \\
\text { loss of bloom }\end{array}$ & $\begin{array}{l}\text { Dull, } \\
\text { sunken, } \\
\text { cloudy }\end{array}$ & & $\begin{array}{c}\text { Some } \\
\text { softening }\end{array}$ & 3 & Acceptable \\
\hline $\begin{array}{c}\text { Catla } \\
\text { (local) }\end{array}$ & $\begin{array}{c}\text { Natural } \\
\text { odour }\end{array}$ & $\begin{array}{c}\text { Natural } \\
\text { odour }\end{array}$ & $\begin{array}{c}\text { Slight } \\
\text { pinkish red }\end{array}$ & $\begin{array}{c}\text { Full bloom; } \\
\text { bright; } \\
\text { shining }\end{array}$ & $\begin{array}{l}\text { Bulging with } \\
\text { protruding } \\
\text { lens }\end{array}$ & $\begin{array}{c}\text { Usually clear, } \\
\text { transparent }\end{array}$ & $\begin{array}{l}\text { Firm and } \\
\text { elastic }\end{array}$ & 1 & Excellent \\
\hline $\begin{array}{c}\text { Catla } \\
\text { (imported) }\end{array}$ & $\begin{array}{c}\text { Loss of } \\
\text { natural } \\
\text { odour }\end{array}$ & $\begin{array}{l}\text { Moderate } \\
\text { to strong } \\
\text { sour odour }\end{array}$ & $\begin{array}{l}\text { Bleached, } \\
\text { brown or } \\
\text { grey colour }\end{array}$ & $\begin{array}{c}\text { Definite } \\
\text { dullness and } \\
\text { no bloom }\end{array}$ & $\begin{array}{l}\text { Sunken eye } \\
\text { covered with } \\
\text { yellow slime }\end{array}$ & & Softening & 5 & $\begin{array}{c}\text { Not } \\
\text { acceptable }\end{array}$ \\
\hline
\end{tabular}

(sample — 54, contaminated-30), 14.81\% kalbaush (sample—54, contaminated—8) and 5.56\% boal (sample54 , contaminated-3) were in average formalin contaminated in these six districts.

It is a matter of great concern that, all the (100\%) imported fishes are formalin contaminated. Combindly in these six districts, in average, 39.44\% (total contaminated sample-213, local contaminated sample-84) local fishes and $60.56 \%$ (total contaminated sample_-213, imported contaminated sample_-129) imported fish were formalin contaminated.

The survey result also revealed that there is a price different between the local and imported fishes is present. In general, local fish and imported fish can be identified by their external appearance, color, size and other morphological characteristics. The result suggested that consumers usually highly prefers local fishes instead of those of imported fishes and the shelf life of the local fishes is much longer than those of imported fishes. The survey also indicates that the overall hygienic and sanitary condition of the market is also very poor. It has also founded in the Gazipur fish market [30].

Table 7 shows that the organoleptic quality of some commercially important local and imported fishes. The scores obtain from the organoleptic assessment reveals that all the local fishes were organoleptically excellent than the imported fishes. The overall quality of the imported fishes was not satisfactory to the consumers and unacceptable [2].

The results indicate that formalin is added in imported fish somewhere in the marketing chain after coming to Bangladesh. Several tests conducted by the Fish Inspection and Quality Control Services (FIQC) of Department of Fisheries (DoF) in Bangladesh in fish immediately after landing in Teknaf port found no incidence of formalin [1]. At the time of landing in Bangladesh, the fishes were found individually packed with polythene in iced conditions. The importers sell these fishes to the different intermediaries. It is likely to assume that the fishes are dipped into formalin solution for a while by some fish traders before transporting to the different retail markets inside the country.

In 2011, the National Toxicology Program, an interagency program of the Department of Health and Human Services, named formaldehyde as a known human carcinogen in its 12th Report on Carcinogens [19]. Though it is harmful and potential source of health hazard to human, some fish traders are engaged in treating fish with formalin. Distribution of formalin contaminated local and imported fish in different districts are presented in Figures 2-5.

It was observed in a study conducted in Dhaka city [9] that almost 5\% shops of total consumable fishes contain formalin treated fishes in the fish markets. They found this intensity varies market to market and species to species. They found that Rui fish was highly affected by formalin, whereas Karwan Bazar represented highest number of formalin treated fish.

\section{Conclusion}

It is clear that day by day, the uses of the formalin are highly increasing. In 2014, the rate of the uses of formalin 


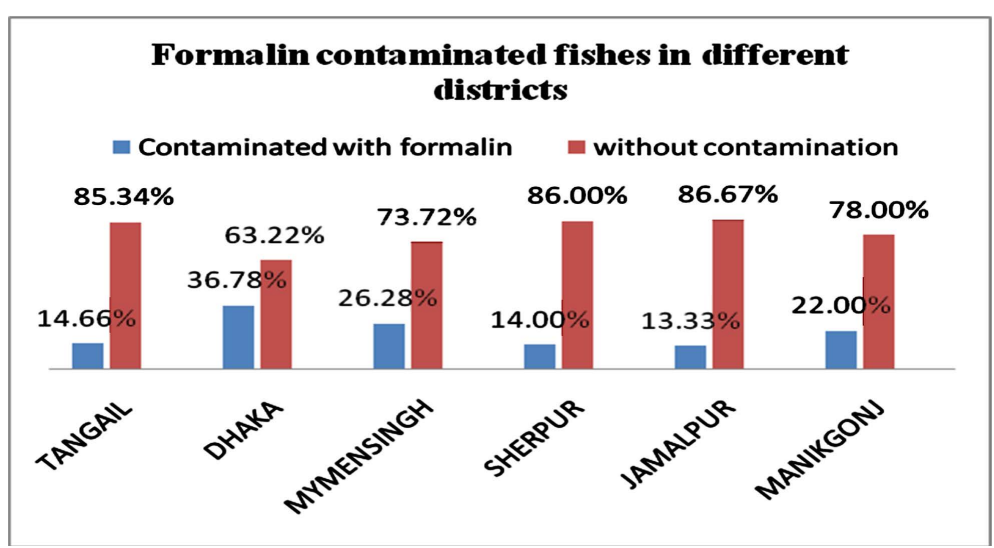

Figure 2. Percent distribution of various types of formalin contaminated fishes.

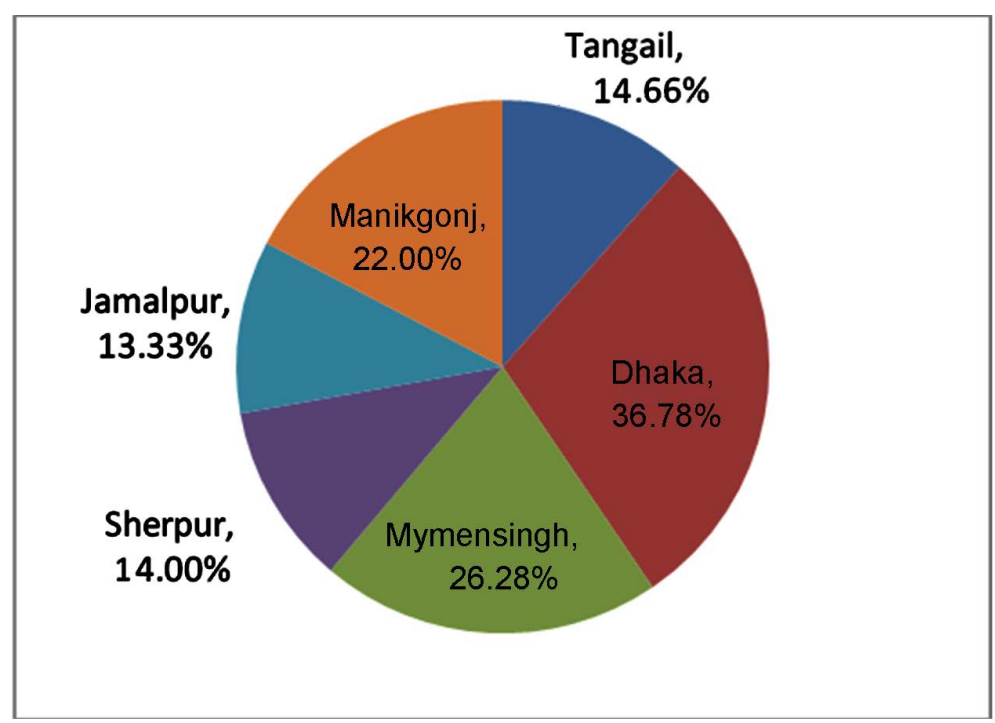

Figure 3. Distribution of Formalin contaminated fish in different district.

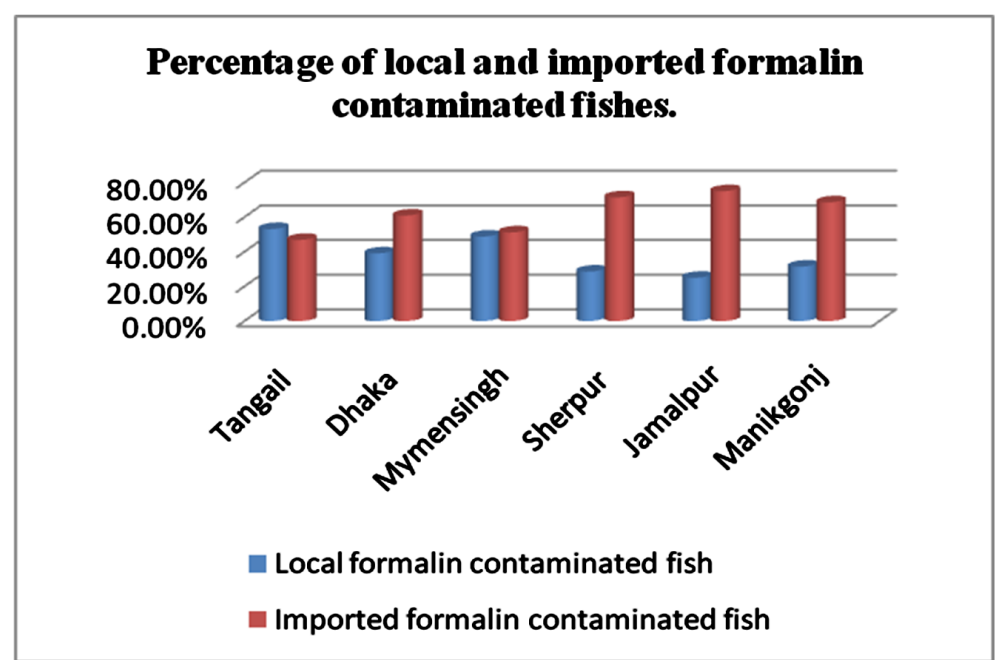

Figure 4. Distribution of formalin contaminated local and imported fish in different district. 


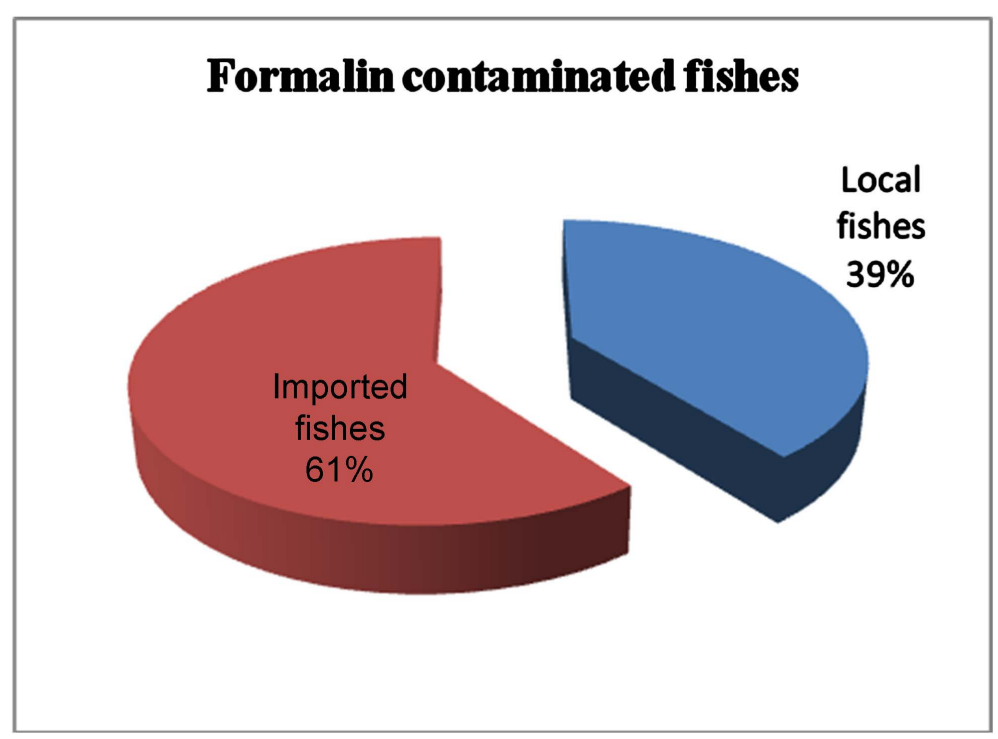

Figure 5. Distribution of formalin contamination in local and imported fish.

in fish raised to double than it was in 2010-2011. As a result, the number of the cancerous diseases is remarkably increasing day by day. It is assumed that formalin is added to the fish, especially those come from bordering countries by the local fish traders to keep the fish fresh for a long time. But as it is a carcinogenic chemical and has got the ability to produce serious health hazards like cancers of the lung, nasopharynx, oropharynx and nasal passage to the population, regulatory bodies should take necessary steps to minimize and stop formalin treatment of the fish. The current study involves a small number of samples to detect formalin in fish in local market in different six districts. But it gives us a comprehensive picture to understand the extent and magnitude of the scenario. Although it is necessary to conduct such type of study in whole value chain in different markets, this study gives an idea of the extent of formalin contamination of fish in Bangladesh. The government and other agencies need to take necessary steps to prevent such type of malevolent activates by the fish traders to safe guard public health.

\section{References}

[1] DoF (Department of Fisheries) (2009) Fish Fortnight Publication. Department of Fisheries, Ministry of Fisheries and Livestock.

[2] Yeasmin, T., Reza, M.S., Khan, M.N.A., Shikha, F.H. and Kamal, M. (2010) Present Status of Marketing of Formalin Treated Fishes in Domestic Markets at Mymensingh District in Bangladesh. International Journal of Biological Research, 1, 21-24.

[3] Kibria, G. (2007) Formalin and Fish Trade in Bangladesh—Human and Environmental Risks. http://www.sydneybashi-bangla.com

[4] MoFL (2011) Ministry of Fisheries \& Livestock, Government of the People’s Republic of Bangladesh. http://www.mofl.gov.bd

[5] FAO (2011) FAO Country Sector Fact Sheets Placeholder. National Aquaculture Sector Overview: Bangladesh. http://www.fao.org/fishery/countrysector/naso_bangladesh/en

[6] Fernandes, G. and Venkatraman, J.T. (1993) Role of Omega-3 Fatty Acids in Health and Disease. Nutrition Research, 13, 19-45. http://dx.doi.org/10.1016/S0271-5317(05)80282-9

[7] Ismail, H.M. (2005) The Role of Omega-3 Fatty Acids in Cardiac Protection: An Overview. Frontiers in Bioscience, 10, 1079-1088. http://dx.doi.org/10.2741/1601

[8] Hossain, M.S., Rahman, M.A., Sharkar, T.K. and Shahjalal, H.M. (2008) Formaldehyde Content in the Rui Fish (Labeo rohita) in Bangladesh and Effect of Formaldehyde on Lipid Peroxidation in Rat Liver and Intestinal Tissues. Journal of Medical Sciences, 8, 405-409. http://dx.doi.org/10.3923/jms.2008.405.409

[9] Haque, E. and Mohsin, A.B.M. (2009) Intensity of Formalin Use for Consumable Fish Preservation in Dhaka City, Bangladesh. Journal of Fisheries International, 4, 51-53. 
[10] Yeasmin, T., Reza, M.S., Shikha, F.H., Khan, M.N.A. and Kamal, M. (2010) Quality Changes in Formalin Treated Rohu Fish (Labeo rohita, Hamilton) during Ice Storage Condition. Asian Journal of Agricultural Sciences, 2, 158-163.

[11] Noordiana, N., Fatimah, A.B. and Farhana, Y.C.B. (2011) Formaldehyde Content and Quality Characteristics of Selected Fish and Seafood from Wet Markets. International Food Research Journal, 18, 125-136. http://www.sydneybashi-bangla.com

[12] Wooster, G.A., Martinez, C.M., Bowser, P.R. and O’Hara, D.S. (2005) Human Health Risks Associated with Formalin Treatments Used in Aquaculture: Initial Study. North American Journal of Aquaculture, 67, 111-113. http://dx.doi.org/10.1577/A04-026.1

[13] Satin, M. (2004) Food Alert: The Ultimate Sourcebook for Food Safety. 2nd Edition, Facts on File, Inc., 111-113.

[14] FAO (2009) World Review of Fisheries and Aquaculture. In: The State of World Fisheries and Aquaculture, Food and Agriculture Organization, Rome.

[15] Khan, M.N.A., Islam, M.N. and Reza, M.S. (2009) Investigation on the Nitrofuran and Their Metabolites and Chemicals Used in Shrimp Feeds and Feed Ingredients: Final Report for Bangladesh Quality Support Program (BQSP)-Fisheries, UNIDO. Project No. EE/BGD/05/B02, 5-6.

[16] Wang, S., Cui, X. and Fang, G. (2007) Rapid Determination of Formaldehyde and Sulfur Dioxide in Food Products and Chinese Herbals. Food Chemistry, 103, 1487-1493.

[17] Bianchi, F., Careri, M., Musci, M. and Mangia, A. (2007) Fish and Food Safety: Determination of Formaldehyde in 12 Fish Species by SPME Extraction and GC-MS Analysis. Food Chemistry, 100, 1049-1053.

[18] Sapthahik (2011) Business Men Using Formalin in Fish. Newspaper Sapthahik-2000, 31 March 2011, Bangladesh.

[19] National Toxicology Program (2011) Report on Carcinogens. 12th Edition, Department of Health and Human Services, Public Health Service, National Toxicology Program.

[20] Uddin, R., Wahid, M.I., Jesmeen, T., Huda, N.H. and Sutradhar, K.B. (2011) Detection of Formalin in Fish Samples Collected from Dhaka City, Bangladesh. Stamford Journal of Pharmaceutical Sciences, 4, 49-52.

[21] Hossain, M.M. (2011) Consumption in Rural Bangladesh: Households, Lifestyles, and Identities. Academic Dissertation, Department of Economics and Management, University of Helsinki, Helsinki.

[22] Passy, R., Kapia, T.A. and Stearling, K. (1983) Shelf Life of Fish and Sea Food. Food Science and Nutrition, 36, 8593.

[23] Woyewoda, A.D., Shaw, S.J., Ke, P.J. and Burns, B.G. (1986) Quality Indices-Lipid Related. In: Recommended Laboratory Methods for Assessment of Fish Quality: Canadian Technical Report of Fisheries and Aquatic Science, Department of Fisheries and Oceans, Halifax.

[24] Kyrana, V.R., Lougovois, V.P. and Valsamis, D.S. (1997) Assessment of Shelf-Life of Maricultured Gilthead Sea Bream (Sparus aurata) Stored in Ice. International Journal of Food Science and Technology, 32, 339-347. http://dx.doi.org/10.1046/j.1365-2621.1997.00408.x

[25] Pons-Sánchez-Cascado, S., Bover-Cid, S., Veciana-Nogués, M.T. and Vidal-Carou, M.C. (2005) Amino Acid-Decarboxylase Activity of Bacteria Isolated from Ice-Preserved Anchovies. European Food Research and Technology, 220, 312-315. http://dx.doi.org/10.1007/s00217-004-1095-y

[26] Reza, M.S., Bapary, M.A.J., Ahasan, C.T., Islam, M.N. and Kamal, M. (2009) Shelf Life of Several Marine Fish Species of Bangladesh during Ice Storage. International Journal of Food Science and Technology, 44, 1485-1494. http://dx.doi.org/10.1111/j.1365-2621.2007.01613.x

[27] López-Caballero, M.E., Huidobro, A., Pastor, A. and Tejada, M. (2002) Microflora of Gilthead Seabream (Sparus aurata) Stored in Ice. Effect of Washing. European Food Research and Technology, 215, 369-400.

[28] Howgate, P.A.J. and Whittle, K.J. (1992) Multilingual Guide to EC Freshness Grades for Fishery Products. Torry Research Station, Food Safety Directorate, Ministry of Agriculture, Fisheries and Food, Aberdeen.

[29] Neely, W.B. (1963) Action of Formaldehyde on Microorganisms-I. Correlation of Activity with Formaldehyde Metabolism. Journal of Bacteriology, 85, 1028-1031.

[30] Ahmed, N., Rahman, M.M. and Rahman, M.M. (2005) A Study on Fish Marketing Systems in Gazipur, Bangladesh. Pakistan Journal of Biological Sciences, 8, 182-192. 
Scientific Research Publishing (SCIRP) is one of the largest Open Access journal publishers. It is currently publishing more than 200 open access, online, peer-reviewed journals covering a wide range of academic disciplines. SCIRP serves the worldwide academic communities and contributes to the progress and application of science with its publication.

Other selected journals from SCIRP are listed as below. Submit your manuscript to us via either submit@scirp.org or Online Submission Portal.
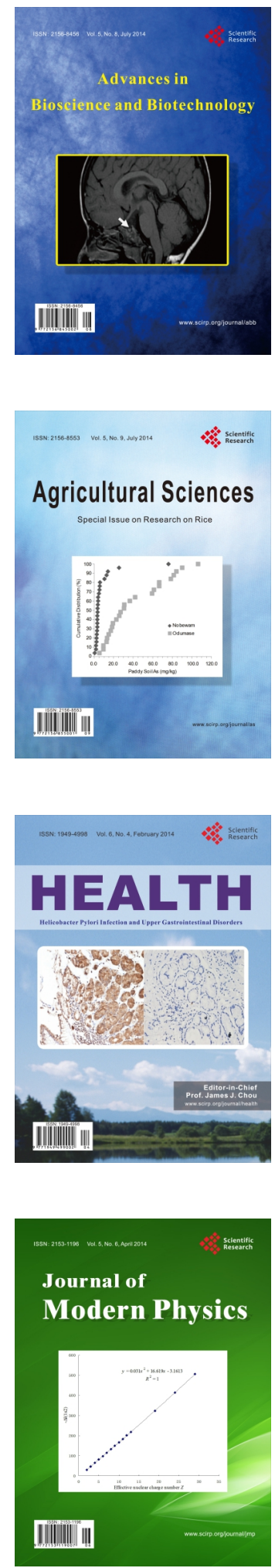
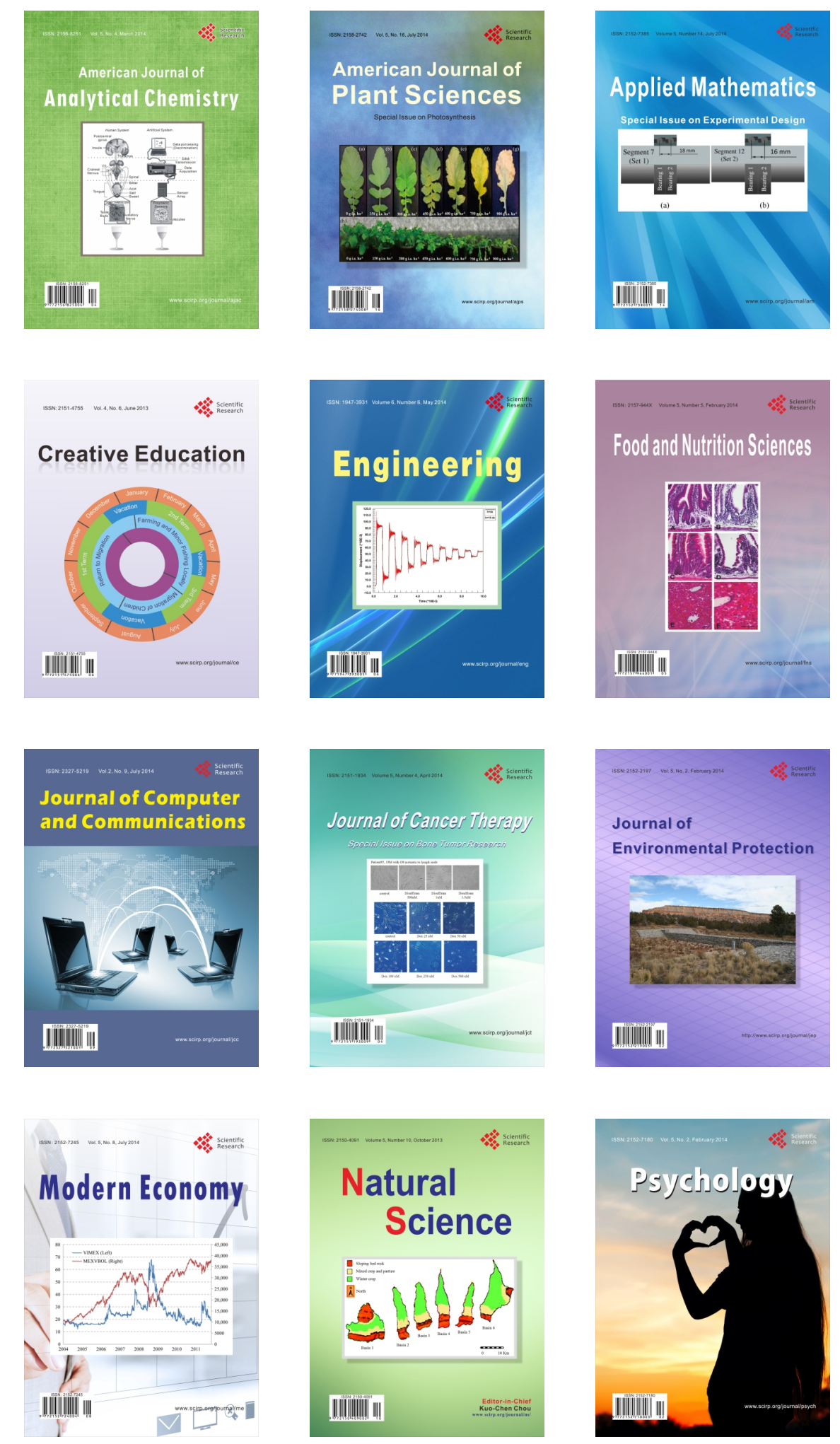